\title{
Áhrif punglyndislyfja og róandi lyfja á árangur af ósértækri hugrænni atferlismeðferð hópa í heilsugæslu
}

\author{
Erik Brynjar Schweitz Eriksson ${ }^{1,2}$ læknir, Hafrún Kristjánsdóttir2,3,4 sálfræðingur, Jón Friðrik Sigurðsson²,4 sálfræðingur, \\ Agnes Agnarsdóttir² sálfræðingur, Engilbert Sigurðsson ${ }^{2,4}$ læknir
}

\section{ÁGRIP}

Inngangur: Rannsóknir á hugrænni atferlismeðferð (HAM) og bunglyndislyfjum sýna marktækan árangur í meðferð kvíða og punglyndis. Sampætting pessara meðferða hefur í sumum tilvikum sýnt fram á árangu umfram einpátta meðferð. Hins vegar virðast benzódíazepín-lyf geta haft neikvæð áhrif á árangur af HAM-einstaklingsmeðferð. Í rannsókn á HAM á námskeiðsformi í heilsugæslu var árangur metinn með tilliti til notkunar á punglyndislyfjum (SSRI/SNRI) annars vegar og benzódíazepínum og zsvefnlyfjum hins vegar.

Efniviður og aðferðir: Árangur af meðferðinni var mældur með Beckspunglyndis- (BDI-II) og kvíðakvörðum (BAI). Notast var við "last observation carried forward"- aðferð (LOCF) par sem fyrsta og síðasta mæling voru bornar saman óháð pví hvenær síðasta mælingin var gerð. Breyting var mæld á meðaltalsskori milli einstaklinga á lyfjum úr tilteknum lyfjaflokkum og borin saman við skor peirra sem ekki voru á slíkum lyfjum. Niðurstöður: Á pví priggja ára tímabili sem gögnunum var safnað tóku
557 einstaklingar pátt i 5 vikna HAM-námskeiðum í heilsugæslunni. Af peim skiluðu 355 einstaklingar BDI-II kvarða og 350 einstaklingar BAIkvarða tvisvar eða oftar. Meðaltalsskor beggja lyfjahópanna lækkaði marktækt á báðum kvörðum. Lækkun á meðaltalsskori peirra sem tóku SSRI/SNRI-punglyndislyf og fengu HAM var marktækt meiri en hinna sem einungis sóttu HAM-námskeiðin. Einnig náðist marktækt meiri árangur hjá peim sem voru á slíkum punglyndislyfjum en hjá hinum sem einnig voru á benzólyfjum og/eđa z-svefnlyfi. Í öđrum tilvikum var ekki marktækur munur á árangri milli hópa.

Ályktun: HAM á námskeiðsformi i heilsugæslunni dregur marktækt úr einkennum kvíða og depurðar, óhád notkun punglyndis- og benzólyfja og/ eða z-svefnlyfja. Slík lyfjanotkun er pví ekki frábending fyrir HAM-hópmeðferð. Við meðferð punglyndis gefur sampætt punglyndislyfjameðferð pó aukinn árangur en sá árangur er minni hjá peim sem einnig taka benzóog/eða z-svefnlyf.
Institute of Psychiatry, King's College, London, ${ }^{2}$ geðsviði Landspítala, ${ }^{3}$ Háskólanum í Reykjavik, ${ }^{4}$ æknadeild Háskóla Íslands.

Fyrirspurnir: Engilbert Sigurðsson prófessor í geðlæknisfræð læknadeild Háskóla Íslands,

yfirlæknir við geðsvið̃ Landspítala Hringbraut

101 Reykjavik

engilbs@landspitali.is

Greinin barst

12. júní 2013 , sampykkt til birtingar

11. október 2013

Engin hagsmunatengs। gefin upp.

\section{Inngangur}

Á síðastliðnum áratug hefur verið mikil umræða um breytt viðhorf Íslendinga til punglyndis og mikla notkun punglyndislyfja á Íslandi. ${ }^{1}$ Árangur hugrænnar atferlismeðferðar (HAM) og punglyndislyfja við meðferð punglyndis og kvíða hefur verið vinsælt rannsóknarefni á undanförnum árum. Bæði meðferðarform hafa sýnt marktækan árangur. ${ }^{2,3}$ Áhrifin af sampættingu pessara tveggja meðferðarforma fram yfir árangur af hvorri meðferð fyrir sig við punglyndi og kvíða hafa verið minna rannsökuðð og teljast pví umdeilanlegri. Ávinningur af HAM er pó ekki eins skýr og af lyfjameðferð við mjög alvarlegu punglyndi., ${ }^{4,5}$ Par virðist sem reynsla og pekking meðferðaraðilans skipti meira máli en pegar um er að ræða meðferð á vægum eða miðlungsalvarlegum punglyndislotum. ${ }^{6}$

Sampætt meðferð par sem lyfjum og HAM er beitt samtímis er ekki óumdeild. Sú gagnrýni hefur komið fram að par sem punglyndislyfin dragi úr einkennum geti pað dregið úr áhugahvöt hins veika til að tileinka sér HAM og sinna meðferðinni. ${ }^{7}$ Á petta einkum við um einstaklinga með felmtursröskun.7 Til að sú vinna sem er forsenda HAM geti farið fram, purfa einkenni felmtursröskunarinnar að vera til staðar.7 Sama umræða hefur átt sér stað varðandi pátt benzódíazepína í meðferð á kvíða og punglyndi. Almennt er talið að slík lyf, sé talið nauðsynlegt að grípa til peirra, ættu helst einungis að hafa pað hlutverk að vera viðbótarmeðferð í afmarkaðan tíma. ${ }^{5}$ I raun er slíkt hægara sagt en gert. Sjúklingar eru oft tregir til að hætta töku peirra og takast í kjölfarið á við aukin kvíðaeinkenni, auk annarra fráhvarfseinkenna, á meðan pau eru tröppuð út.

Nýlega hafa kerfisbundnar greiningar (meta-analyses) sýnt fram á að sampætt sálfræði- og punglyndislyfjameðferð við punglyndi er árangursríkari en hvor meðferðin fyrir sig., ${ }^{89}$ Höfundum er ekki kunnugt um rannsóknir á áhrifum benzódíazepín-lyfja á áhrif HAM við punglyndi. Fyrstu rannsóknir bentu til að benzódíazepín-notkun gæti dregið úr áhrifum $\mathrm{HAM}^{10}$ í meðferð kvíða. Í síðari rannsóknum kom svo fram að notkun á benzódíazepínum eftir pörfum dró enn frekar úr árangri af HAM en regluleg notkun peirra.,11

HAM er öflugri meðferð við almennri kvíðaröskun en benzódíazepínlyf og árangur af sampættri meðferð er par svipaður og af HAM einni og sér.12 Takmarkaður ávinningur er af pví að bæta punglyndislyfi við HAM við almennri kvíðaröskun. ${ }^{13}$ Hvað áráttu-práhyggjuröskun varðar, hefur ekki verið sýnt með afgerandi hætti fram á að sampætt meðferð sé betri eða síðri en punglyndislyf eða HAM.7 Benzódíazepín-notkun dregur úr árangri HAM við felmtursröskun ${ }^{14}$ og pá helst ef um langtímanotkun er að ræða. ${ }^{15}$ Í vönduðum nýlegum yfirlitsgreinum kemur fram að sampætt meðferð (HAM 
og punglyndislyf) sé árangursríkari til skemmri tíma en gefi svipaðan langtímaárangur og HAM ein og sér við felmturs- og áfallastreituröskun. ${ }^{16-18}$

Rauði práðurinn í fyrri rannsóknum á meðferð kvíða virðist vera að langtíma ávinningur af sampættri meðferð með HAM og punglyndislyfjum sé svipaður og af HAM einni, en skammtímaáhrif sampættrar meðferðar reynist í sumum tilvikum meiri. Óvissa er um hvort benzódíazepínlyf kunni að draga úr virkni HAM-meðferðar. Pau virðast ýmist hafa haft engin eða neikvæð áhrif á árangur HAM við meðferð kvíðaraskana. ${ }^{11,12}$ Áhrif hinna náskyldu z-svefnlyfja (til dæmis zopiclone og zolpidem) á árangur HAM-meðferðar hafa nær ekkert verið rannsökuð, en pau verka á GABA-viðtaka með mjög líkri verkun og benzódíazepínlyf.

Pótt HAM-hópmeðferð hafi verið talsvert rannsökuð og ýmis afbrigði hennar litið dagsins ljós, er lítið um rannsóknir á pví hver séu áhrif mikið notaðra geðlyfja á árangur af HAM-hópmeðferð. ${ }^{19}$ Í nýlegri rannsókn var árangur af sampættri meðferð, phenelzín og HAM-hópmeðferð, borin saman við einpátta meðferð við félagskvíða. Par reyndist sampætta meðferðin árangursríkari en hvor einpátta meðferðin fyrir sig. ${ }^{20}$

Markmið pessarar rannsóknar var að kanna hvort notkun algengra geðlyfja eins og SSRI/SNRI-punglyndislyfja (SSRI= Selective Serotonin Reuptake Inhibitors; SNRI= Serotonin and Noradrenalin Reuptake Inhibitors), og notkun benzólyfja og z-svefnlyfja hefði truflandi áhrif á árangur ósértækrar HAM-meðferðar á námskeiðsformi við meðferð punglyndis og kvíða. Раð er afar mikilvægt að fá svör við peirri spurningu fyrir tilvísendur og pá sem hyggjast nýta sér meðferðina, par sem miklum fjölda einstaklinga er vísað í sambærileg HAM-námskeið árlega á Íslandi. Flestir peirra eru sjúklingar heilsugæslunnar, en margir sækja einnig slík námskeið á göngudeild geðsviðs Landspítala. Um helmingur peirra sem vísað er í slíka meðferð í heilsugæslunni er að taka eitt eða fleiri lyf úr ofangreindum lyfjaflokkum.

\section{Efniviður og aðferðir}

Sálfræðingar á geðsviði Landspítalans hafa á síðustu 9 árum próað notkun HAM á námskeiðsformi í meðferð kvíða og punglyndis fyrir 15-30 einstaklinga í senn. Námskeiðin hafa farið fram á Landspítala og heilsugæslustöðvum. Gögnum sem rannsókn pessi byggir á var safnað á HAM-námskeiðum á 7 mismunandi heilsugæslustöðvum á höfuðborgarsvæðinu og tveimur stöðvum á landsbyggðinni. Heimilislæknar og hjúkrunarfræðingar á pessum stöðvum gátu vísað sérhverjum einstaklingi 18 ára og eldri með væg til miðlungsalvarleg kvíða- og/eða punglyndiseinkenni í meðferðina. Í hverjum meðferðarhópi voru allt að 25 manns. Pátttakendur gátu haldið áfram að sækja hefðbundna meðferð hjá sínum heilsugæslulækni meðan á HAM-meðferð stóð. Slík meðferð fólst oftast í lyfjameðferð og/eða stuðningsviðtölum. Tveir sálfræðingar sáu um HAM-meðferðina á hverri heilsugæslustöð. Leitast var við að tryggja að annar meðferðaraðilinn hefði haldið námskeiðið tvisvar eða oftar ef hinn var að halda pað í fyrsta sinn. Meðferðin var í formi námskeiðs í tvær klukkustundir í senn vikulega í 5 vikur. Peir sem heimilislæknar vísuðu í meðferðina voru boðaðir í greiningarviðtal fyrir meðferð par sem lagt var fyrir stutt staðlað greiningarviðtal, MINI-International Neuro- psychiatric Interview (MINI). ${ }^{21,22}$ Beck's Depression Inventory-II (BDI-II) punglyndiskvarðinn ${ }^{23,24}$ og Beck's Anxiety Inventory (BAI) kvíðakvarðinn ${ }^{25,26}$ voru einnig lagðir fyrir pátttakendur í greiningarviðtali. Rannsóknin hlaut leyfi Persónuverndar (S2602/2005) og vísindasiðanefndar (VSNb20050900003/03-15).

Ferns konar frábendingar voru fyrir pátttöku í meðferðinni: 1) geðrofseinkenni, 2) áfengis- eða vímuefnavandi, 3) heilabilun eða önnur greindarskerðing sem truflað gæti pátttöku í HAM, 4) аð vera ekki orðinn 18 ára.

Við úrvinnslu rannsóknarinnar voru einungis notaðar niðurstöður peirra pátttakenda sem: a) reyndust hafa punglyndis- og/ eða kvíðagreiningu samkvæmt MINI, eða skoruðu yfir viðmiðunarmörkum á BDI-II (>13 stig) eða BAI (>9 stig) og b) mættu að minnsta kosti í einn meðferðartíma, og svöruðu spurningalistum. Á pví priggja ára tímabili, 2005-2007, sem gögnunum var safnað uppfylltu 355 manns pessi skilyrði og voru niðurstöður peirra notaðar í úrvinnslunni. Meðalaldur pátttakenda var 38,6 ár (staðalfrávik 13,0 ár; spönn: 18-73 ára). Konur voru 303 (85\%) en karlar $52(15 \%)$.

Pátttakendur voru flokkaðir eftir pví hvort peir tóku geðlyf eða ekki og pá hvaða geðlyf peir notuðu. Af peim 355 einstaklingum sem notaðir voru í úrvinnslunni voru 108 á SSRI/SNRI punglyndislyfi, 29 á benzódíazepínlyfi og/eða z-svefnlyfi, 42 einstaklingar á SSRI/SNRI-punglyndislyfi og einnig á benzódíazepínlyfi og/eða z-lyfi, alls 179 manns. Nær jafnmargir, 176 einstaklingar, tóku ekki lyf úr pessum algengu lyfjaflokkum.

Peir sem tóku sértæka serótónín endurupptökuhamlara (SSRI) eða serótónín og noradrenalín endurupptökuhamlara (SNRI) voru flokkaðir saman í einn hóp, par sem lyfin í pessum flokkum eru mest notuðu punglyndislyf á Íslandi ${ }^{27}$ auk pess sem virkni peirra og virknisetur eru fremur svipuð í algengustu skammtastærðum. Fjöldi einstaklinga á öðrum punglyndislyfjum reyndist of lítill til að hægt væri að meta sérstaklega hvort áhrif peirra væru frábrugðin áhrifum SSRI/SNRI-lyfja.

Í ljósi niðurstaðna fyrri rannsókna á áhrifum benzódíazepína á einstaklings-HAM voru peir sem voru á lyfjum úr flokki benzódíazepína og/eða benzódíazepín-skyldra svefnlyfja, z-lyfja, sem tengjast sömu GABA-viðtökum og hafa lík lyfhrif flokkaðir saman í einn hóp til að auka styrk (power) í samanburði einstakra undirhópa. Ekki var greint á milli tegunda lyfja innan flokkanna.

Ofangreindir lyfjaflokkar voru skoðaðir sérstaklega par sem í peim er að finna pau lyf sem eru langmest notuð hér á landi í lyfjameðferð við vægum til miðlungsalvarlegum punglyndis- og kvíðaröskunum og í meðferð svefnröskunar sem oft fylgir slíkum veikindum. ${ }^{28}$

Árangur meðferðarinnar var mældur með Beck's punglyndis(BDI-II) og kvíðakvörðum (BAI) en pessir listar voru lagðir fyrir pátttakendur í greiningarviðtali, fyrsta, priðja og fimmta meðferðartíma. Notast var við svokallaða "last observation carried forward"-aðferð (LOCF) par sem fyrsta og síðasta mæling voru bornar saman, óháð pví hvenær síðasta mælingin var gerð. Leyft var að ekki væri merkt við allt að 15\% atriða í BDI-II og BAI. Ef gildi vantaði var meðaltal annarra gilda reiknað og sett inn fyrir pað gildi sem vantaði. Breytingar á meðaltalsskori peirra sem voru á SSRI/SNRI-lyfjum og peirra sem voru á benzódíazepínum eða z-lyfjum voru borin saman við breytingar á skori peirra sem ekki voru á slíkum lyfjum. Í 5 tilfellum slepptu pátttakendur að svara fjórum eða fleiri atriðum á BAI-sjálfsmatskvarðanum. Vegna 
Tafla I. Meðaltöl (M) og staðalfrávik (SF) fyrir og eftir ósértæka HAM-hópmeðferð á sjúklingum heilsugæslunnar með Becks-punglyndiskvarða, BDI-Il, og Beckskvíðakvarða, BAI.

\begin{tabular}{|c|c|c|c|c|c|c|c|c|}
\hline \multirow[t]{2}{*}{ BDI-II } & \multicolumn{2}{|c|}{ Ekki umrædd lyf* $(\mathrm{N}=176)$} & \multicolumn{2}{|c|}{ Benzólyf/z lyf (N=29) } & \multicolumn{2}{|c|}{ SSRI/SNRI lyf (N=108) } & \multicolumn{2}{|c|}{ Benzó/z + SSRI/SNRI (N=42) } \\
\hline & M & Sf & M & Sf & M & Sf & M & Sf \\
\hline Upphaf & 23,43 & 9,57 & 18,35 & 8,66 & 25,97 & 10,34 & 24,87 & 10,19 \\
\hline Lok & 17,58 & 11,92 & 12,68 & 8,95 & 16,27 & 11,63 & 20,03 & 12,16 \\
\hline \multirow[t]{2}{*}{ BAI } & \multicolumn{2}{|c|}{ Ekki umrædd lyf* ( $N=175$ ) } & \multicolumn{2}{|c|}{ Benzólyf/z lyf (N=28) } & \multicolumn{2}{|c|}{ SSRI/SNRI lyf (N=106) } & \multicolumn{2}{|c|}{ Benzó/z + SSRI/SNRI (N=41) } \\
\hline & M & Sf & M & Sf & M & Sf & M & Sf \\
\hline Upphaf & 18,84 & 11,49 & 16,76 & 8,85 & 20,74 & 11,99 & 22,87 & 12,39 \\
\hline Lok & 13,47 & 10,82 & 13,37 & 9,33 & 13,97 & 10,01 & 16,77 & 13,21 \\
\hline
\end{tabular}

*Ekki á benzólyfjum, z-svefnlyfjum, SSRI/SNRI-lyfjum

pessa var ekki hægt að notast við heildarskor listans við úrvinnslu á BAI-niðurstöðum peirra. Tveir af pessum 5 einstaklingum sem skiluðu ekki inn fullgildum BAI-listum voru á SSRI/SNRI-punglyndislyfi, einn á benzó- og/eða z-lyfi, einn einstaklingur var á SSRI/SNRI-punglyndislyfi og einnig á benzódíazepínlyfi og/eða z-lyfi og einn tók ekki lyf úr pessum flokkum (tafla I).

Notast var við fervikagreiningu/marghliða dreifigreiningu (ANOVA/ANCOVA) og Gabriels eftir-á próf (post hoc test) við úrvinnslu gagnanna, par sem breyting var mæld á meðaltalsskori í upphafi meðferðar og við eftirfylgd milli ofangreindra hópa. Tölfræðilegt marktæki tvískotta (two-tailed) p-gilda var sett við $<0,05$. Allir útreikningar voru gerðir í tölfræðiforritinu SPSS, útgáfu 12.1.

\section{Niðurstödur}

Á pví priggja ára tímabili sem gögnunum var safnað tóku 557 einstaklingar pátt í 5 vikna HAM-námskeiðum í heilsugæslunni. Af peim skiluðu 355 einstaklingar BDI-II kvarða og 350 einstaklingar BAI-kvarða tvisvar eða oftar. Tölulegar niðurstöður rannsóknarinnar eru dregnar saman í töflu I. Par má finna meðaltalsskor hinna fjögurra undirflokka úrtaksins á BDI-II og BAI-kvörðunum í upphafi meðferðar og við síðustu mælingu.

\section{Punglyndiseinkenni (BDI-II)}

Munur var á upphafskorum á BDI-II milli hópa $(\mathrm{F}(3,351)=4,19$, $\mathrm{p}>0,05$ ). Niðurstöður Gabriels eftir-á prófs (post hoc test) sýndu að punglyndiseinkenni peirra sem voru á benzódíazepínlyfi og/ eða z-lyfi voru marktækt lægri við upphaf meðferðar heldur en peirra sem voru á SSRI/SNRI-punglyndislyfi $(p=0,002)$ og peirra sem ekki tóku lyf úr pessum algengu lyfjaflokkum $(p=0,045)$. Ekki var munur á punglyndiseinkennum í upphafi meðferðar milli annarra hópa ( $\mathrm{p}>0,05)$. Megináhrif HAM-meðferðar í námskeiðsformi voru marktæk $(\mathrm{F}(1,351)=92,96, \mathrm{p}<0,001)$, skor allra pátttakenda á BDI-II punglyndiskvarðanum voru marktækt lægri í lok meðferðar en við upphaf hennar.

Skoðað var hvort samvirkni væri milli árangurs meðferðar og lyfjaflokka. Marktæk samvirkni reyndist til staðar milli minnkunar á punglyndiseinkennum frá upphafsmælingu á BDI-II til lokamælingar og undirhópa $(\mathrm{F}(3,351)=4,22, \mathrm{p}<0,05)$. Árangur meðferðarinnar var pví ekki hinn sami í öllum hópunum. Gert var Gabriel-eftir-á-próf til að greina á milli hvaða hópamunur væri á árangri. Niðurstöður prófsins sýndu að árangur punglyndis- meðferðarinnar var marktækt betri hjá pátttakendum sem tóku SSRI/SNRI-punglyndislyf en peim sem voru ekki á slíkum lyfjum $(\mathrm{p}=0,01)$. Einnig var marktækt meiri árangur hjá peim sem voru á SSRI/SRNI punglyndislyfi en hjá hinum sem einnig voru á SSRI/ SRNI-lyfi en jafnframt á benzó- og/eða z-svefnlyfi ( $\mathrm{p}=0,037)$. Ekki reyndist marktækur munur á árangri milli annarra hópa. Taka verður fram að hópur peirra sem tók benzó- og/eða z-lyf en ekki SSRI/SNRI-lyf var langfámennastur og kann ástæða pess að ekki fannst munur á breytingaskori pess hóps og peirra sem taka SSRI/ SNRI-lyf að vera að styrkur prófsins sé ekki nægur vegna fárra pátttakenda í fyrrnefnda hópnum.

Mynd 1 sýnir breytingar á BDI-II skori fyrir og eftir hópmeðferð. Á myndinni má sjá að meðaltalslækkun skors peirra sem voru á SSRI/SNRI-punglyndislyfi en ekki á benzólyfi eða z-svefnlyfi var tæplega tvöfalt meiri en lækkun skora peirra sem voru í öðrum flokkum úrtaksins. Af niðurstöðunum má pví álykta að HAMmeðferð í námskeiðsformi skili árangri en ef til vill meiri árangri hjá fólki sem er einnig á SSRI/SNRI-punglyndislyfi samanborið við pá sem ekki eru á umræddum lyfjum eða eru á SSRI/SNRI-lyfi en taka jafnframt benzó- og/eða z-svefnlyf. Ekki er hægt að álykta að meðferðin skili peim sem eru ekki á SSRI/SNRI-lyfjum betri árangri en peim sem eru á benzó- og/eða z-lyfi, hvort sem SSRI/ SNRI-lyf eru tekin samhliða benzó- og/eða z-lyfi eða ekki.

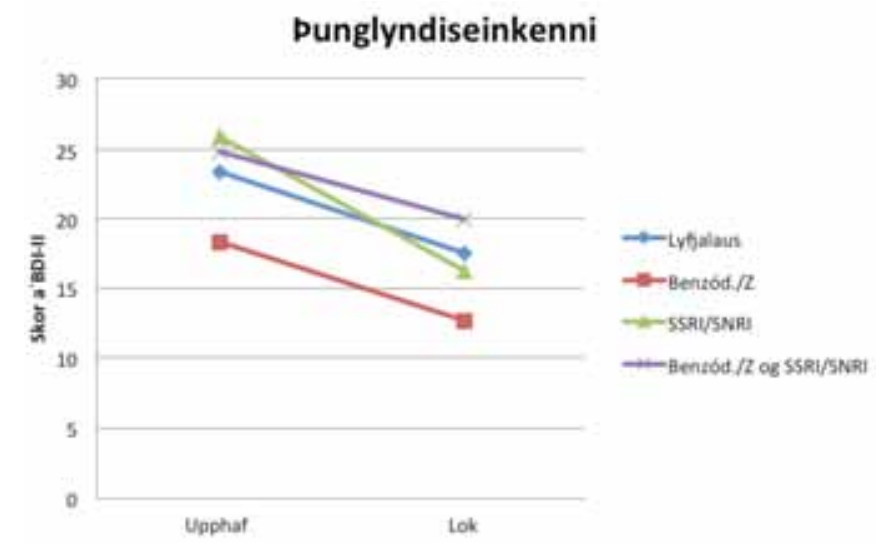

Mynd 1. Skor á BDI-II fyrir og eftir meðferð, greint eftir undirhópum. 


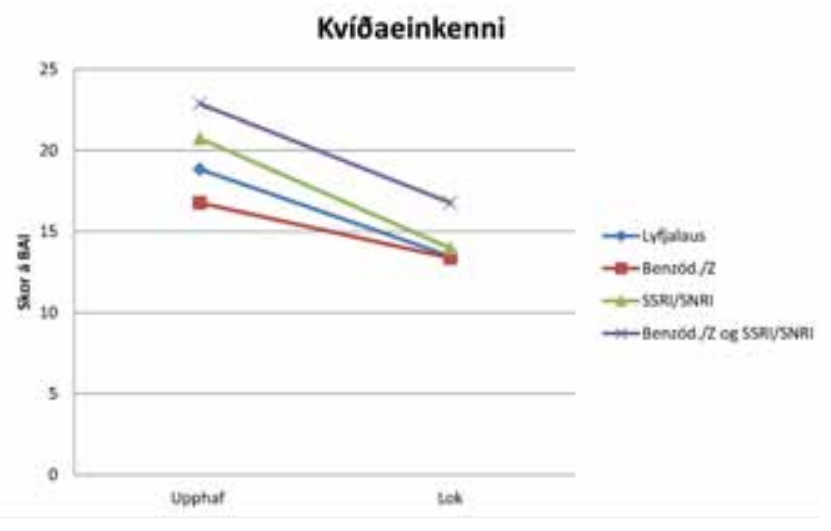

Mynd 2. Skor á BAI fyrir og eftir meðferð, greint eftir undirhópum.

Kvídaeinkenni (BAI)

Ekki var marktækur munur á upphafskorum á BAI milli hópa $(\mathrm{F}(3,346)=2,11, \mathrm{p}>0,099)$ en munurinn var pó ekki langt frá mörkum marktektar. Megináhrif meðferðar voru marktæk $(\mathrm{F}(1,346)=60,2$, $\mathrm{p}<0,001)$. Skor pátttakenda á BAI-kvíðaskalanum voru marktækt lægri í lok meðferðar en við upphaf meðferðar. Metið var hvort samvirkni væri milli árangurs meðferðar og lyfjaflokka. Ekki kom fram marktæk samvirkni á milli breytingaskors á BAI og einstakra undirhópa $(\mathrm{F}(3,346)=0,97, \mathrm{p}=0,41)$. Árangur meðferðar reyndist pví sambærilegur hvað varðar breytingar á kvíða fyrir einstaka hópa.

Mynd 2 sýnir breytingar á skorum fyrir og eftir lyfjameðferð. Á myndinni má sjá að lækkun á BAI-skorum reyndist sambærileg fyrir einstaka undirhópa. Minnkun kvíðaeinkenna er pó aðeins minni hjá hópnum sem er á benzólyfjum og/eða z-lyfjum en hinum hópunum, pótt pað nái ekki marktækni, en jafnframt er styrkur kvíðaeinkenna minnstur hjá peim hópi í upphafi. Af niðurstöðum má pví álykta að meðferðin hafi sambærileg áhrif á kvíðaeinkenni óháð undirhópum.

Einnig var gerð dreifigreining par sem bornir voru saman peir sem voru á SSRI/SNRI-lyfi og peir sem ekki voru á peim lyfjum, óháð pví hvort einstaklingar í samanburðarhópnum væru á benzódíazepínum/z-lyfjum eða ekki. Jafnframt voru breytingar á meðaltalsskori einstaklinga á benzódíazepínum/z-lyfjum bornar saman við skor peirra sem ekki voru á peim lyfjum, óháð punglyndislyfjanotkun. Sambærilegar niðurstöður fengust par og í ofangreindum eftir-á prófum.

\section{Umræða}

Eins og kemur fram í inngangi hefur sampætt meðferð lyfja og HAM sem einstaklingsmeðferðar verið mikið rannsökuð. Í rannsókn okkar var HAM-meðferðin á námskeiðsformi, ætluð allt að 25 manns í senn. Ekki hefur áður verið rannsakað, svo að höfundar viti til, hvort notkun punglyndislyfja og róandi lyfja hafi áhrif á petta hagkvæma meðferðarform HAM líkt og gert hefur verið í tilviki einstaklings-HAM. Pó mætti ætla að áhrifin kynnu að vera svipuð par sem hugmyndafræðin bak við HAM-einstaklingsmeðferð og HAM-hópmeðferð á námskeiðum er sú sama.

Helstu niðurstöður rannsóknarinnar eru að hugræn atferlismeðferð á námskeiðsformi virðist gagnast einstaklingum með vægan til miðlungsalvarlegan kvíða- og punglyndisvanda, hvort sem peir taka einnig SSRI/SNRI punglyndislyf og/eða benzódíazepínlyf/z-svefnlyf.

Á BDI-II punglyndiskvarða var marktækt meiri lækkun á skori peirra sem voru á SSRI/SNRI-punglyndislyfjum en hjá peim sem ekki voru á slíkum lyfjum. Er pað í takt við niðurstöður fyrri samanburðarrannsókna og kerfisbundinnar greiningar á einstaklings-HAM. ${ }^{6,7}$ Tilvísun í HAM á námskeiðsformi er pví alls ekki frábending fyrir pví að hefja punglyndismeðferð með SSRI/ SNRI-lyfi, telji læknir pörf á pví, til að mynda ef talsverð bið er eftir að námskeið hefjist. Með tilliti til punglyndiseinkenna virtist pað auka árangur HAM-námskeiðsins að einstaklingurinn væri á slíkum lyfjum á sama tíma og HAM-námskeiðið átti sér stað. Á móti peim viðbótarávinningi verður hins vegar að vega pætti eins og aukaverkanir og kostnað af töku punglyndislyfjanna.

Peir sem tóku bæði punglyndis- og benzódíazepínlyf/z-lyf náðu lakari svörun í meðferð punglyndis en peir sem tóku punglyndislyf en ekki benzódíazepínlyf/z-lyf. Hér ber pó að taka fram að pað er ólíklegt að peir hópar séu fyllilega sambærilegir par sem ekki er um tvíblinda slembirannsókn að ræða. Pessar niðurstöður benda pó til pess að pað kunni að vera skynsamlegt að forðast að bæta benzódíazepín eða z-lyfjum við punglyndislyfjameðferð einstaklinga með punglyndiseinkenni ef vísa á peim í HAM-meðferð á námskeiðsformi.

Hvað kvíðaeinkenni varðar fundum við ekki marktækan mun á meðferðarárangri milli peirra sem voru á SSRI-/SNRI-punglyndislyfjum og hinna sem ekki voru á slíkum lyfjum. Ekki kom heldur fram marktækur munur á árangri peirra sem voru á benzódíazepínlyfjum og/eða z-lyfjum og peirra sem ekki tóku slík lyf meðan á HAM-meðferð stóð. Er pað í takt við pað sem sumar fyrri rannsóknir á einstaklings-HAM hafa sýnt hvað benzódíazepínlyfin varðar. ${ }^{10}$ Hafa ber pó í huga að smæð benzódíazepín-hópsins getur haft áhrif á pær niðurstöður vegna lítils styrks tölfræðinnar fyrir fámennan hóp. Hins vegar er færsla (trend) í átt að lakari árangri af meðferðinni hjá einstaklingum á benzódíazepínlyfjum sem sjá má á minni lækkun á BAI-skorum peirra en hinna sem ekki eru á slíkum lyfjum. Niðurstöður pessarar rannsóknar mæla pví ekki gegn fyrri niðurstöðum og klínískum leiðbeiningum um að halda notkun á benzódíazepínlyfjum í lágmarki við meðferð kvíðaraskana, og séu pau notuð, að reyna pá að takmarka notkun peirra við skammtímameðferð..$^{12,13}$

Раð er vissulega veikleiki í rannsókninni að um priðjungur (202) peirra sem upphaflega tók pátt í meðferðinni skilaði ekki BDI-II eða BAI-spurningarlistum tvisvar eða oftar og nýttust svör peirra pví ekki í pessum hluta rannsóknarinnar. Pað er pó brottfallshlutfall sem parf ekki að koma á óvart í rannsókn sem gerð er sem hluti af almennri heilbrigðispjónustu á vegum heilsugæslunnar. Aftur á móti er pað styrkleiki rannsóknarinnar að heildarfjöldi pátttakenda var mikill. Fáar erlendar rannsóknir par sem slíkt meðferðarform er metið hafa náð að safna slíkum fjölda pátttakenda.

Áhugavert er að fremur fáir af peim sem var vísað í meðferðina voru að nota benzódíazepínlyf eða z-lyf. Einnig er pað styrkur rannsóknarinnar að hún er gerð við sömu aðstæður og áætlað er að veita meðferðina við til lengri tíma. Meðferðin verður áfram veitt við vægum til miðlungsalvarlegum punglyndis- og kvíðavanda af sálfræðingum sem hafa allir fengið sömu pjálfun og með sama sniði í heilsugæslu hér á landi. Einnig telst pað styrkleiki 
að pátttakendum var ekki ljóst að áhrif lyfjameðferðar á árangur yrðu metin. Pví er ólíklegt að lyfjanotkun peirra hafi litað sjálfsmat peirra á BAI og BDI-II-kvörðunum.

Í rannsókninni var lagt upp með að skoða ávinning af HAM á námskeiðsformi og hvort notkun algengra punglyndislyfja, róandi lyfja og algengustu svefnlyfja hefði mögulega neikvæð áhrif á pann ávinning. Niðurstöðurnar sýna að pátttakendur hafa marktækan ávinning af meðferðinni og að notkun ofangreindra lyfja er ekki frábending fyrir HAM-hópmeðferð í heilsugæslunni hér á landi, enda reyndist árangur punglyndismeðferðar raunar mestur hjá peim sem einnig taka punglyndislyf.

\section{Pakkir}

Höfundar pakka Ástu Jónasdóttur, Margréti Ólafíu Tómasdóttur og Maríu Hrönn Nikulásdóttur hjálp við gagnasöfnun og ritrýnum fyrir margar góðar ábendingar. Einnig viljum við pakka Baldri Heiðari Sigurðssyni aðstoð við tölfræðiúrvinnslu. Að lokum pökkum við sálfræðingum á geðsviði, starfsfólki heilsugæslunnar og peim fjölmörgu sjúklingum sem komu að rannsókninni með einum eða öðrum hætti fyrir peirra mikilvæga framlag og gott samstarf.

\section{Heimildir}

1. Sigurðsson E, Ólafsdóttir P, Gottfreðsson M. Public views on antidepressant treatment: lessons from a national survey. Nord J Psychiatry 2008; 62: 374-8.

2. Cuijpers P, van Straten A, van Oppen P, Andersson G. Are psychological and pharmacologic interventions equally effective in the treatment of adult depressive disorders? A meta-analysis of comparative studies. J Clin Psychiatry 2008; 69: 1675-85

3. Sighvatsson $\mathrm{MB}$, Kristjansdottir $\mathrm{H}$, Sigurdsson $\mathrm{E}$ Sigurdsson JF. Gagnsemi hugrænnar atferlismeðferðar við lyndis- og kvíðaröskunum hjá fullorðnum. Læknablaðið 2011; 97: 613-9.

4. Thase ME, Friedman ES. Is psychotherapy an effective treatment for melancholia and other severe depressive states? J Affect Disord 1999; 54: 1-19.

5. National Institute for Health and Care Excellence 2009. The treatment and management of depression in adults. CG90. National Institute for Health and Care Excellence, London.

6. DeRubeis RJ, Hollon SD, Amsterdam JD, Shelton RC, Young PR, Salomon RM, et al. Cognitive therapy vs medications in the treatment of moderate to severe depression. Arch Gen Psychiatry 2005; 62: 409-16.

7. Black D. Efficacy of Combined Pharmacotherapy and Psychotherapy versus Monotherapy in the Treatment of Anxiety Disorders. CNS Spectr 2006; 11: 10: 29-33.

8. Cujipers P, Dekker J, Hollon SD, Andersson G. Adding psychotherapy to pharmacotherapy in the Treatment of Depressive Disorders in adults: A Meta-Analysis. J Clin Psychiatry 2009; 70: 1219-29.

9. Pampallona S, Bollini P, Tibaldi G, Kupelnick B, Munizza C. Combined pharmacotherapy and psycosocial treatment for depression: a systematic review. Arch Gen Psychiatry 2004; 61: 714-9.

10. Marks IM, Swinson RP, Basoglu M, Kuch K, Noshirvani $\mathrm{H}, \mathrm{O}^{\prime}$ Sullivan G, et al. Alprazolam and exposure alone and combined in panic disorder with agoraphobia. A controlled study in London and Toronto. Br J Psychiatry 1993; 162: 776-87.
11. Westra HA, Stewart SH: CBT and pharmacotherapy: complimentary or contradictory approaches ot the treatment of anxiety? J Clin Psychiatry 1998; 18: 307-40.

12. Power KG, Simpson RJ, Swanson V, Wallace LA. Controlled comparison of pharmacological and psychological treatment of generalized anxiety disorder in primary care. Br J Gen Pract 1990; 40: 289-94.

13. Bandelow B, Seidler-Brandler U, Becker A, Wedekind D, Rüther E. Meta-analysis of randomized controlled comparisons of psychopharmacological and psychological treatments for anxiety disorders. World J Biol Psychiatry 2007; 8: 175-87.

14. Watanabe N, Churchill R, Furukawa TA. Combination of psychotherapy and benzodiazepines versus either therapy alone for panic disorder: a systematic review. BMC Psychiatry 2007; 5: 18

15. National Institute for Health and Care Excellence 2011. Generalised anxiety disorder and panic disorder (with or without agoraphobia) in adults. CG113. National Institute for Health and Care Excellence, London.

16. Furukawa TA, Churchill R, Watanabe N. Combined psychotherapy plus antidepressants for panic disorder with or without agoraphobia (Review). Cochr Datab Syst Rev 2007; 4: 467-8601.

17. Hetrick SE, Purcell R, Garner B, Parslow R. Combined pharmacotherapy and psychological therapies for post traumatic stress disorder (PTSD). Cochr Datab Syst Rev 2010; 6: 7.

18. van Apeldoorn FJ, Timmerman ME, Mersch PP, van Hout WJ, Visser S, et al. A randomized trial of cognitivebehavioral therapy or selective serotonin reuptake inhibitor or both combined for panic disorder with or without agoraphobia: treatment results through 1-year follow-up. J Clin Psychiatry 2010; 71: 574-86.

19. Hans E, Hillier W. Effectiveness of and dropout from outpatient cognitive behavioral therapy for adult unipolar depression: a meta-analysis of nonrandomized effectiveness studies. J Consult Clin Psychol 2013; 81: 75-88.
20. Blanco $\mathrm{C}$, Heimberg RG, Schneier FR, Fresco DM, Chen $\mathrm{H}$, Turk CL, et al. A placebo-controlled trial of phenelzine, cognitive behavioral group therapy, and their combination for socialanxiety disorder. Arch Gen Psyciatry 2010; 67: 286-95.

21. Sheehan DV, Lecrubier $Y$, Sheehan KH, Amorim P, Janavs J, Weiller, et al. The Mini-International Neuropsychiatric Interview (M.I.N.I.): the development and validation of a structured diagnostic psychiatric interview for DSM-IV and ICD-10. J Clin Psychiatry 1998; 59 Suppl 20: 22-33; quiz 34-57.

22. Sigurdsson, BH. Comparison between two standardised psychiatric interviews and two self-report measures: MINI, CIDI, PHQ and DASS (Cand Psych). University of Iceland, Reykjavík 2008.

23. Beck AT, Steer RA, Brown GK. BDI-II, Beck Depression Inventory II: Manual (2nd ed.). The Psychological Corporation, Harcourt, Brace, and Company, Boston 1996.

24. Arnarson TO, Olason DT, Smari J, Sigurdsson JF. The Beck Depression Inventory Second Edition (BDI-II): psychometric properties in Icelandic student and patient populations. Nord J Psychiatry 2008; 62: 360-5.

25. Beck AT, Epstein N, Brown G, Steer RA. An inventory for measuring clinical anxiety. Psychometric properties. J Consult Clin Psychol 1988; 56: 893-7.

26. Sæmundsson BR, Thorsdottir F, Kristjansdottir H, Olason DP, Smari J, Sigurdsson JF. Psychometric properties of the Icelandic version of the Beck Anxiety Inventory in a clinical and a student population. Eur J Psychol Assess 2011; 27: 133-41.

27. Helgason T, Tomasson H, Zoëga T. Antidepressants and public health in Iceland. Time series analysis of national data. Br J Psychiatry 2004; 184: 157-62.

28. sjukra.is/lyf-og-hjalpartaeki/lyf/skyrslur-um-lyfjakostnad/ - maí 2013 


\title{
ENGLISH SUMMARY
}

\section{The effect of antidepressants and sedatives on the efficacy of transdiagnostic cognitive behavioral therapy in groups in primary care}

\author{
Eriksson EBS ${ }^{1,2}$, Kristjansdottir $\mathrm{H}^{2,3,4}$, Sigurdsson $\mathrm{JF}^{2,4}$, Agnarsdottir $\mathrm{A}^{2}$, Sigurdsson $\mathrm{E}^{2,4}$
}

Background: Cognitive behavioral therapy (CBT) and SSRI/SNR antidepressants have proven to be effective treatments for anxiety and depression. The gain from combined CBT and antidepressant therapy has in some studies been greater than from monotherapy. Benzodiazepines may interfere with the efficacy of individual CBT-treatment. We examined the effects of SSRI/SNRI antidepressants and the effects of benzodiazepines/z-drugs on the efficacy of group CBT (gCBT) in primary care.

Material and methods: Primary outcome measures were the Beck's Depression Inventory II (BDI-II) and the Beck's Anxiety Inventory (BAI) scores before treatment and after the last session. The last observed score was carried forward and compared to the initial score for each individual, irrespective of the timing of the last score (LOCF). Mean change of scores was compared between groups of individuals on or not on SSRI/SNRI antidepressants and/or benzodiazepines/z-drugs.

Results: Over three years 557 subjects participated in a 5 week-long
$\mathrm{gCBT}$. Of these 355 returned $\mathrm{BDI}-\mathrm{II}$ and 350 returned $\mathrm{BAI}$ at least twice. The mean score on SSRI/SNRI or benzo/z-drugs fell significantly both for those on combined treatment (medication and gCBT) and those who only received gCBT. Combined treatment with SSRI/SNRI and gCBT led to a greater fall in depressive symptoms compared to gCBT monotherapy. The efficacy of such combined treatment was less for those who also were prescribed benzodiazepines and/or z-drugs.

Conclusions: Group CBT significantly improved symptoms of anxiety and depression in primary care. The improvement was not reduced by concomitant use of SSRI/SNRI antidepressants nor of benzodiazepines/ z-hypnotics. The use of such medication is therefore not contraindicated for gCBT participants, at least not short term. Adding SSRIs or SNRIs to gCBT led to greater efficacy in reducing depressive symptom though the efficacy of such combined treatment was less for those who were also prescribed benzodiazepines and/or z-hypnotics.

Key words: Group-CBT, transdiagnostic CBT, antidepressants, benzodiazepines, anxiety, depression.

Correspondence: Engilbert Sigurdsson, engilbs@landspitali.is

${ }^{1}$ Institute of Psychiatry, King's College University, ${ }^{2}$ Mental Health Services, Landspitali-The National University Hospital of Iceland., ${ }^{3}$ Reykjavik University, ${ }^{4}$ Faculty of Medicine, University of Iceland 